\title{
Nitrate Dissimilation by Vibrio spp. Isolated From Estuarine Sediments
}

\author{
By G. T. MACFARLANE AND R. A. HERBERT* \\ Department of Biological Sciences, University of Dundee, Dundee DDI 4HN, Scotland, U.K.
}

(Received 11 January 1982; revised 26 March 1982)

\begin{abstract}
The generic distribution of nitrate-respiring bacteria in tidal mudflats of six Scottish east-coast river estuaries has been determined. The predominant bacteria involved were identified as Aeromonas/Vibrio spp., together with lower numbers of enterobacteria. Pseudomonads accounted for only a small proportion of the nitrate-respiring populations. Samples of sediment from all the estuaries produced nitrite and ammonia after $7 \mathrm{~d}$ incubation at $15^{\circ} \mathrm{C}$ with added nitrate. Studies with the isolate Vibrio V48 and strains of Vibrio parahaemolyticus (NCMB 1903 and NCMB 2047) demonstrated that when these bacteria were grown anaerobically under conditions of glucose limitation, nitrite was the primary product of nitrate respiration, whereas ammonia was excreted into the medium when nitrogen was limiting. Nitrate reduction was accompanied by the synthesis of a particulate nitrate reductase and under $\mathrm{N}$-limitation a nitrite reductase was also induced.
\end{abstract}

\section{INTRODUCTION}

Many bacteria can use nitrate as a terminal electron acceptor in the absence of molecular $\mathrm{O}_{2}$ (Payne, 1973; Herbert et al., 1980). The end-products of nitrate respiration depend upon the bacterium and the growth conditions. In bacteria such as Paracoccus denitrificans, Thiobacillus denitrificans and Pseudomonas aeruginosa the products are gaseous $\left(\mathrm{N}_{2} \mathrm{O}\right.$ and $\left.\mathrm{N}_{2}\right)$ and the process is more correctly termed denitrification. Alternatively, nitrate may be reduced via nitrite to ammonia. This process has been demonstrated in a number of fermentative bacteria such as Klebsiella spp. (Hadjipetrou \& Stouthamer, 1965; Dunn et al., 1978), Escherichia coli (Cole, 1978) and Achromobacter fischeri (Prakash \& Sadana, 1973). The respiratory reduction of nitrate is catalysed in most bacteria by a membrane-bound nitrate reductase (Thauer et al., 1977) and a soluble nitrite reductase (Kemp \& Atkinson, 1966; Dunn et al., 1978). Energetically, nitrate respiration is superior to fermentative metabolism and a number of studies have demonstrated that this respiratory process is coupled to phosphorylation (Stouthamer, 1977; Thauer et al., 1977).

Dunn et al. (1979) showed that in $K$. aerogenes $\mathrm{K} 312$ nitrate reduction occurred at dissolved $\mathrm{O}_{2}$ tensions of $15 \mathrm{mmHg}(2 \mathrm{kPa})$ and below. These conditions prevail immediately below the oxidized surface layer of marine and estuarine sediments. Studies with $\left[{ }^{15} \mathrm{~N}\right]$ nitrate have shown that nitrate reduction to ammonia occurred in these sediments (Koike \& Hattori, 1978; Sorensen, 1978). Dunn et al. (1980) showed that Aeromonas/Vibrio spp. were the predominant nitratereducing bacteria present in sediments in the Tay estuary. Preliminary physiological studies with one isolate (Vibrio V25) indicated that this bacterium was unable to reduce nitrate beyond nitrite even under $\mathrm{N}$-limiting conditions. In this paper we describe the role of nitrate as an alternative electron acceptor in another isolate, Vibrio V48, and in two strains of Vibrio parahaemolyticus when grown under anaerobic conditions, and consider how this correlates with the synthesis of a membrane-bound nitrate reductase and a soluble nitrite reductase.

\section{METHODS}

Organisms. Nitrate-respiring bacteria were isolated from sediment samples obtained from the estuaries of the Don, North Esk, South Esk, Tay and Leven according to the scheme of Dunn et al. (1980). Samples (10 ml) of 
sediment were diluted in sterile Ringer's solution and $0.1 \mathrm{ml}$ volumes of suitable dilutions were plated on to nitrate agar. Plates were incubated anaerobically in an atmosphere of $\mathrm{H}_{2}$ and $\mathrm{CO}_{2}$ for $7 \mathrm{~d}$ at $15^{\circ} \mathrm{C}$. For each estuary, 50 colonies were picked at random from the plates and replated on the same medium to check purity. Each isolate was then tested for its ability to grow in nitrate broth culture and further characterized by the Gram-stain, catalase, oxidase and oxidation-fermentation test (glucose as substrate) using methods described by Cowan (1974).

Vibrio V48 was isolated by direct plating of sediment samples from Kingoodie Bay, Tay estuary, Scotland, on nutrient agar plates plus $0.1 \%(\mathrm{w} / \mathrm{v}) \mathrm{KNO}_{3}$. Type strains of Vibrio parahaemolyticus (NCMB 1903 and NCMB 2047) were obtained from the National Collection of Marine Bacteria, Torry Research Station, Aberdeen.

Growth in continuous culture. The bacteria were grown in a single-stage 1 litre chemostat as described by Baker (1968). The defined medium of Evans et al. (1970) was used, with the concentration of all nutrients lowered by $50 \%$. The concentrations of the carbon source (glucose) and nitrogen source $\left(\mathrm{KNO}_{3}\right)$ were varied as required. $\mathrm{A}$ dilution rate $(D)$ of $0.05 \mathrm{~h}^{-1}$ was used throughout. The growth temperature was maintained at $25^{\circ} \mathrm{C}$ by the use of a Churchill thermocirculator (Churchill Instruments, Perivale, London). The culture was aerated by sparging with sterile compressed air $\left(2.51 \mathrm{~min}^{-1}\right)$, whilst for anaerobic conditions the air supply was replaced by high-purity $\mathrm{N}_{2}$ (Air Products).

Preparation of cell extracts. Extracts were prepared from bacteria grown in the chemostat, as described by Dunn et al. (1979).

Enzyme assays. Nitrate reductase activity was determined in soluble and particulate fractions using the method of Lowe \& Evans (1964), in which benzylviologen reduced with dithionite served as electron donor. This method was not suitable for the two strains of $V$. parahaemolyticus, and nitrate reductase activity in these bacteria was determined by following the nitrate-dependent oxidation of NADH in Thunberg cuvettes. The method used was a modification of the nitrite reductase assay (Cole et al., 1974) in which $20 \mu \mathrm{mol} \mathrm{NaNO} \mathrm{Nas}_{3}$ wabstituted for $\mathrm{NO}_{2}^{-}$. Nitrite reductase was determined in soluble fractions, incubated anaerobically in Thunberg cuvettes, according to the method of Cole et al. (1974). Nitrite reductase was only detected in the soluble fractions.

Determination of bacterial populations. Population densities were determined as described by Dunn et al. (1979).

Nitrate reduction by sediment slurries. This was determined according to the method of Dunn et al. (1980).

Analysis of spent media. Spent media were analysed for nitrite and ammonia according to the methods described by Dunn et al. (1978).

Protein estimation. The Lowry method was used with bovine serum albumin as standard.

Chemicals. Benzylviologen was obtained from Sigma. All other chemicals were of Analar grade and obtained from B.D.H.

\section{RESULTS}

\section{Nitrate reduction in sediment slurries}

Preliminary experiments were performed to determine whether sediment samples obtained from five different Scottish east-coast river estuaries reduced nitrate to nitrite and ammonia. All the samples tested produced both nitrite and ammonia following the addition of nitrate (Table 1). Sediment samples from the Tay and Don produced nitrite as the principal product, whereas with those from the North Esk, South Esk and Leven ammonia was the major product. The proportion of added nitrate dissimilated varied considerably from estuary to estuary $(13 \%$ for the Don to $41 \%$ for the Leven).

\section{Characterization of nitrate-reducing bacteria}

Serial dilutions of sediment from each river estuary were plated on to nitrate agar and incubated under anaerobic conditions. After incubation for $7 \mathrm{~d}$ at $15^{\circ} \mathrm{C}, 50$ colonies were selected at random and classified to genus level (Table 2). On the basis of a limited number of morphological and biochemical tests, Aeromonas/Vibrio spp. were predominant, together with lower numbers of enterobacteria. Pseudomonads only occurred in appreciable numbers in the coarser sandy sediments from the North Esk. Sediment samples were taken in autumn, spring and summer from each river estuary and, whilst the exact proportion of each genus present showed some variation, the predominance of fermentative bacteria identified as Aeromonas/ Vibrio spp. was confirmed. None of the Aeromonas/Vibrio spp. or enterobacteria produced gas when inoculated into nitrate broth. One isolate, Vibrio V48, was selected for further study together with two strains of $V$. parahaemolyticus (NCMB 1903 and 2047). 
Table 1. Nitrite and ammonia production from sediment samples obtained from Scottish east-coast rivers

Sediment samples were incubated at $15^{\circ} \mathrm{C}$ for $7 \mathrm{~d}$ and then the concentrations of nitrite and ammonia measured.

\begin{tabular}{|c|c|c|c|}
\hline Estuary & Addition & $\begin{array}{c}\text { Nitrite produced } \\
{\left[\mu \mathrm{g} \mathrm{N}(\mathrm{ml} \text { sediment })^{-1}\right]}\end{array}$ & $\begin{array}{l}\text { Ammonia produced } \\
{\left[\mu \mathrm{g} \mathrm{N}(\mathrm{ml} \text { sediment })^{-1}\right]}\end{array}$ \\
\hline Don & $\begin{array}{c}\text { None } \\
2 \mathrm{mM}^{-K \mathrm{KO}_{3}} \\
10 \mathrm{mM}-\mathrm{KNO}_{3}\end{array}$ & $\begin{array}{c}0 \\
2 \cdot 49 \\
6 \cdot 97\end{array}$ & $\begin{array}{l}0.57 \\
0.52 \\
1.37\end{array}$ \\
\hline North Esk & $\begin{array}{c}\text { None } \\
2 \mathrm{mM}^{-K \mathrm{KO}_{3}} \\
10 \mathrm{mM}^{-K \mathrm{KO}_{3}}\end{array}$ & $\begin{array}{c}0 \\
1 \cdot 14 \\
1 \cdot 85\end{array}$ & $\begin{array}{l}0.42 \\
2 \cdot 01 \\
1 \cdot 76\end{array}$ \\
\hline South Esk & $\begin{array}{c}\text { None } \\
2 \mathrm{mM}^{-K \mathrm{KO}_{3}} \\
10 \mathrm{mM}-\mathrm{KNO}_{3}\end{array}$ & $\begin{array}{l}0 \cdot 51 \\
2 \cdot 87 \\
2 \cdot 26\end{array}$ & $\begin{array}{l}0 \cdot 84 \\
5 \cdot 19 \\
3 \cdot 13\end{array}$ \\
\hline Tay & $\begin{array}{c}\text { None } \\
2 \mathrm{mM}^{-K \mathrm{KO}_{3}} \\
10 \mathrm{~mm}-\mathrm{KNO}_{3}\end{array}$ & $\begin{array}{l}2 \cdot 56 \\
6 \cdot 63 \\
8 \cdot 35\end{array}$ & $\begin{array}{l}0 \cdot 18 \\
2 \cdot 22 \\
2 \cdot 46\end{array}$ \\
\hline Leven & $\begin{array}{c}\text { None } \\
2 \mathrm{mM}^{-\mathrm{KNO}_{3}} \\
10 \mathrm{~mm}-\mathrm{KNO}_{3}\end{array}$ & $\begin{array}{c}0 \\
0.03 \\
2 \cdot 13\end{array}$ & $\begin{array}{l}0 \cdot 37 \\
8 \cdot 04 \\
5 \cdot 87\end{array}$ \\
\hline
\end{tabular}

Table 2. Identification to genus level of 250 randomly selected nitrate-respiring bacteria isolated from Scottish east-coast estuarine sediments

\begin{tabular}{lcccccc}
\multicolumn{5}{c}{} & \multicolumn{5}{c}{$\begin{array}{c}\text { Gram-positive } \\
\text { Estuary }\end{array}$} & Aeromonas/Vibrio & Alcaligenes & Enterobacteriaceae & Pseudomonas & Unidentified \\
Don & 35 & 5 & 7 & 1 & 2 & 0 \\
North Esk & 27 & 1 & 5 & 14 & 1 & 2 \\
South Esk & 29 & 3 & 7 & 5 & 4 & 2 \\
Tay & 24 & 0 & 12 & 9 & 5 & 0 \\
Leven & 25 & 1 & 14 & 2 & 5 & 3
\end{tabular}

\section{Physiology of nitrate reduction}

When Vibrio V48 was grown anaerobically on nitrate under C-limitation, the cell population density decreased to $42 \%$ of that recorded under aerobic conditions and there was a significant increase in the particulate (membrane-bound) nitrate reductase (Table 3). No nitrite reductase activity was observed under these growth conditions; this is reflected by the accumulation of nitrite in the spent medium (Table 3). The excreted nitrite under anaerobic conditions accounted for $42 \%$ of the nitrate input. On the other hand, under $\mathrm{N}$-limitation the cell population density of Vibrio V48 under anaerobic conditions was $70 \%$ of that observed aerobically and high activities of both a particulate nitrate and a soluble nitrite reductase were recorded. Spent media analyses showed the almost complete absence of nitrite and the accumulation of ammonia (Table 3). In addition to the data presented on Vibrio V48, we have obtained similar results for a number of other Vibrio spp. (Vibrio V27, Vibrio V29, Vibrio V39 and Vibrio V44) isolated from Tay estuary sediments (R. A. Herbert, unpublished results).

To confirm that nitrate reduction to nitrite and ammonia was not confined to these Vibrio isolates, the experiments were repeated with $V$. parahaemolyticus strains NCMB 1903 and 2047. When $V$. parahaemolyticus NCMB 2047 was grown anaerobically under C-limitation, a cell population density was $29 \%$ of that observed under aerobic conditions, and this was associated with the synthesis of a membrane-bound nitrate reductase (Table 3). Unlike the dissimilatory enzyme from Vibrio V48, however, nitrate reductase activity in both strains of $V$.parahaemolyticus was linked only to NADH and no activity was observed with reduced benzylviologen. Spent 
Table 3. Influence of nitrogen and carbon limitation on the aerobic and anaerobic reduction of nitrate by Vibrio V48 and V. parahaemolyticus NCMB 2047

Under C-limitation the medium input contained 5 glucose $\mathrm{l}^{-1}$ and $20 \mathrm{~mm}$-nitrate, whereas under $\mathrm{N}$-limitation the glucose concentration was increased to $15 \mathrm{~g}^{-1}$ and nitrate concentration decreased to 5 mM. $D=0.05 \mathrm{~h}^{-1}, 25^{\circ} \mathrm{C}$.

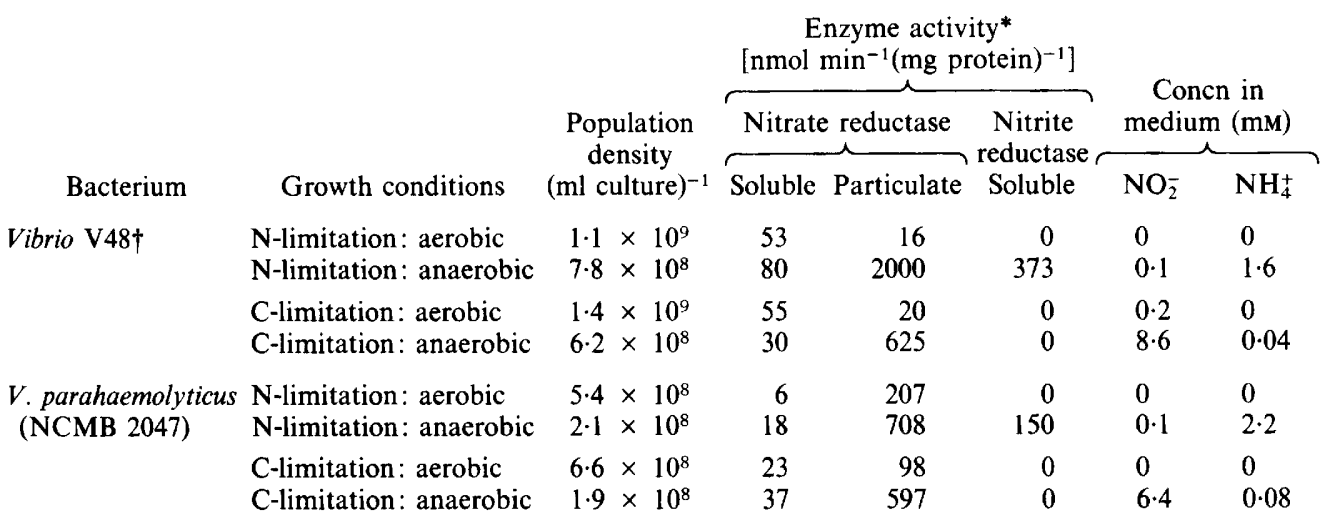

* Mean values of four replicate determinations on separate occasions.

† Vibrio V48 nitrate reductase activities are $\mathrm{nmol} \mathrm{NO}_{2}^{-}$produced $\mathrm{min}^{-1}$ (mg protein) ${ }^{-1}$; all other enzyme activities are nmol $\mathrm{NADH}$ oxidized $\mathrm{min}^{-1}$ (mg protein $)^{-1}$.

media analyses showed that nitrite was the principal product of nitrate reduction under $\mathrm{C}$ limitation (Table 3 ) and accounted for $32 \%$ of the nitrate input. Under $\mathrm{N}$-limitation the anaerobic population density was $39 \%$ of that obtained with aerobically grown cultures, and high activities of nitrate reductase and nitrite reductase were recorded in extracts. Ammonia was the principal end-product and accounted for $44 \%$ of the nitrate input. Similar results were obtained with Vibrio parahaemolyticus NCMB 1903 . These results unequivocally demonstrate that Vibrio spp. can use nitrate as electron acceptor under anaerobic conditions with the concomitant excretion of nitrite under $\mathrm{C}$-limitation, and ammonia under $\mathrm{N}$-limitation.

\section{DISCUSSION}

Sediment samples from a number of Scottish east-coast river estuaries produced nitrite and ammonia when supplemented with nitrate (Table 1). These data support the conclusions of Sorensen (1978) and Koike \& Hattori (1978) that dissimilatory nitrate reduction may account for a significant proportion of the ammonia present in estuarine and marine sediments. The rate of ammonia production observed in the Scottish east-coast estuarine sediments investigated ranged from a maximum of $1.14 \mu \mathrm{g} \mathrm{N} \mathrm{ml}^{-1} \mathrm{~d}^{-1}$ (Leven estuary) to a minimum of $0.4 \mu \mathrm{g} \mathrm{N} \mathrm{ml} \mathrm{N}^{-1}$ $\mathrm{d}^{-1}$ (Don estuary). These rates are approximately 10-30\% of those reported by Sorensen (1978) for the Limfjorden, Denmark. In experiments using $\left[{ }^{15} \mathrm{~N}\right]$ nitrate, Koike \& Hattori (1978) showed that in sediments from Tokyo bay between 7 and $52 \%$ of the added nitrate was dissimilated to ammonia.

The predominant nitrate-reducing bacteria isolated from the estuaries studied belong to the genera Aeromonas/Vibrio. These data confirm and extend the initial studies by Dunn et al. (1980) that Aeromonas/Vibrio spp. were the principal nitrate-dissimilating bacteria in estuarine and marine environments. Preliminary physiological studies with one isolate, Vibrio V25, indicated that this bacterium had a restricted ability to dissimilate nitrate and that it would not compete effectively in situ with those bacteria e.g. Klebsiella spp. which reduced nitrite to ammonia when nitrate is limiting (Herbert et al., 1980). It would appear paradoxical that the dominant nitraterespiring bacteria in these estuarine sediments should have such a restricted role.

Re-examination of nitrate dissimilation by vibrios, as reported here, showed that individual Vibrio spp. were able to dissimilate nitrate under anaerobic conditions and that this was 
associated with a membrane-bound nitrate reductase and a soluble nitrite reductase (Table 3). Since our classification scheme for the Vibrio spp. was based on a limited number of characters, we used known strains of marine vibrios ( $V$.parahaemolyticus NCMB 1903 and NCMB 2047) to confirm that members of this genus could dissimilate nitrate to ammonia (Table 3). Nitrate reduction has also been reported previously in Achromobacter fischeri (Prakash \& Sadana, 1973), which has now been reclassified as $V$. fischeri (Hendry et al., 1970).

A major feature of the nitrate reductase from the type strains of $V$. parahaemolyticus and a number of the Vibrio spp. studied (Vibrio V27, Vibrio V29, Vibrio V39 and Vibrio V44), but not of Vibrio V48, was the requirement in vitro for NADH rather than reduced benzylviologen as electron donor. Vibrio V48 nitrate reductase was able to use both benzylviologen and NADH as electron donor. These data are in agreement with a number of authors who have demonstrated that NADH may serve as an electron donor for nitrate reduction in extracts (Cole \& Wimpenny, 1968; Lester \& De Moss, 1971). The levels of NADH-linked nitrate reductase activity observed in the anaerobically grown Vibrio cultures were similar to those reported for the benzylviologenlinked enzyme in Klebsiella K312 (Herbert et al., 1980) and Klebsiella aerogenes NCIB 418 (Cole \& Brown, 1980).

In conclusion, these results show that fermentative bacteria, and particularly isolates identified as Aeromonas/Vibrio spp., are numerically dominant and potentially the most active nitratereducing bacteria in a number of Scottish east-coast estuarine sediments. Nitrate dissimilation in these bacteria was associated with the synthesis of a membrane-bound nitrate reductase and, under nitrate-limiting conditions, a soluble nitrite reductase. Neither enzyme was repressed when cultures were pulsed with ammonia $\left(10 \mathrm{~mm}-\mathrm{NH}_{4} \mathrm{Cl}\right)$, except when nitrate was omitted from the growth medium. However, the synthesis of both enzymes was repressed by oxygen, thereby confirming their dissimilatory role in nitrate reduction. Whilst these results establish that nitrate reduction to ammonia can occur in estuarine sediments, the relative significance of dissimilatory nitrate reduction to ammonia and ammonification from organic nitrogen detritus in estuarine sediments still needs to be assessed.

We are grateful to the Natural Environmental Research Council for Grant GR/3/4208 which has financed this work.

\section{REFERENCES}

BAKER, K. (1968). Low cost continuous culture apparatus. Laboratory Practice 17, 817-821.

COLE, J. A. (1978). The rapid accumulation of large quantities of ammonia during nitrite reduction by Escherichia coli. FEMS Microbiology Letters 4, 327329.

Cole, J. A. \& Brown, C. M. (1980). Nitrite reduction to ammonia by fermentative bacteria: a short circuit in the biological nitrogen cycle. FEMS Microbiology Letters 7, 65-72.

Cole, J. A. \& WimpenNy, J. W. T. (1968). Metabolic pathways of nitrate reduction in Escherichia coli. Biochimica et biophysica acta 162, 39-48.

Cole, J. A., Coleman, K. J., Compton, B. E., KavenaGh, B. M. \& Keevil, C. W. (1974). Nitrite and ammonia assimilation by anaerobic cultures of Escherichia coli. Journal of General Microbiology 85, 11-22.

Cowan, S. T. (1974). Manual for the Identification of Medical Bacteria. Cambridge: Cambridge University Press.

DunN, G. M., Herbert, R. A. \& Brown, C. M. (1978). Physiology of denitrifying bacteria from tidal mudflats in the River Tay. In Physiology and Behaviour of Marine Organisms, pp. 135-140. Edited by D. S. McLusky \& A. J. Berry. Oxford: Pergamon Press.
Dunn, G. M., Herbert, R. A. \& Brown, C. M. (1979). Influence of oxygen tension on nitrate reduction by a Klebsiella sp. growing in chemostat culture. Journal of General Microbiology 112, 379-383.

Dunn, G. M., Wardell, J. N., Herbert, R. A. \& Brown, C. M. (1980). Enrichment, enumeration and characterisation of nitrate reducing bacteria present in sediments of the River Tay Estuary. Proceedings of the Royal Society of Edinburgh 78b, 47-56.

Evans, C. G. T., Herbert, D. \& Tempest, D. W. (1970). The continuous culture of microorganisms. Methods in Microbiology 2, 277-327.

Hadjipetrou, L. P. \& Stouthamer, A. H. (1965). Energy production during nitrate respiration by Aerobacter aerogenes. Journal of General Microbiology 38, 29-34.

Hendry, M. S., Hodgkiss, W. \& Shewan, J. M. (1970). Identification, taxonomy and classification of luminous bacteria. Journal of General Microbiology 64, 151-169.

Herbert, R. A., Dunn, G. M. \& Brown, C. M. (1980). The physiology of nitrate dissimilatory bacteria from the Tay estuary. Proceedings of the Royal Society of Edinburgh 78b, 79-87.

KEMP, J. D. \& AtKinson, D. E. (1966). Nitrite reductase of $E$. coli specific for reduced nicotinamide 
adenine dinucleotide. Journal of Bacteriology 92 , 628-638.

KoIKE, I. \& HATTORI, A. (1978). Denitrification and ammonia formation in anaerobic coastal sediments. Applied and Environmental Microbiology 35, 278-282.

LESTER, R. L. \& DE Moss, J. A. (1971). Effects of molybdate and selenite on formate and nitrate metabolism in Escherichia coli. Journal of Bacteriology 105, 1006-1014.

Lowe, R. H. \& Evans, H. J. (1964). Preparation and some properties of a soluble nitrate reductase from Rhizobium japonicum. Biochimica et biophysica acta 85, 377-389.

PAyne, W. J. (1973). Reduction of nitrogenous oxides by microorganisms. Bacteriological Reviews 37, 409452 .
Prakash, O. \& Sadana, J. C. (1973). Metabolism of nitrate in Achromobacter fischeri. Canadian Journal of Microbiology 19, 15-25.

SKERMAN, V. B. D. (1967). A Guide to the Identification of the Genera of Bacteria, 2nd edn. Baltimore: Williams \& Wilkins.

SORENSEN, J. (1978). Capacity for denitrification and reduction of nitrate to ammonia in a coastal marine sediment. Applied and Environmental Microbiology 35, 301-305.

Stouthamer, A. H. (1977). Energetic aspects of the growth of micro-organisms. Symposia of the Society for General Microbiology 27, 285-315.

Thauer, R. K., Jungermann, K. \& Decker, K. (1977). Energy conversion in chemotrophic anaerobic bacteria. Bacteriological Reviews 41, 100-180. 